\title{
Income polarization, the middle class and informal employment in Greater Buenos Aires, 1974-2010
}

\author{
Fernando Groisman
}

ABSTRACT

This article examines the social structure of Argentina's main conurbation, Greater Buenos Aires, over the past four decades. The research focused on identifying changes in society by stratifying it into three social classes: high, middle and low. Contributions are made in three areas. First, the article engages with the renewed debates about methodology on the issue of which criteria are best suited to achieving an adequate demarcation of social classes, especially the middle class. Second, it uses a variety of approaches to document changes in the social structure with a view to identifying common trends. Lastly, it highlights certain dominant features of the workings of the labour market that appear to have left their mark on the social morphology of Argentina.

KEYWORDS

JEL CLASSIFICATION

AUTHOR
Social structure, social classes, middle class, labour market, family incomes, income distribution, cities, statistics, Argentina

J31, D31, J21

Fernando Groisman is a researcher at the National Science and Technology Council (CONICET) and the University of Buenos Aires (UBA). fgroisman@ conicet.gov.ar 


\section{I}

\section{Introduction}

Research into the characteristics and dynamics of the social structure has become a topical issue, and justifiably so, given the repercussions that far-reaching transformations in the international economic system have been having in recent times. The focus of attention has been on developments in the middle classes right across the world, although the research hypotheses this evolution entails can be seen to vary depending on the region or country concerned.

For one thing, the growth of middle-income sectors in a large group of Asian and Latin American countries has changed the face of global society and created an interest in comprehending the characteristics of this new social contingent (Kharas, 2010; Ravallion, 2010; Castellani and Parent, 2011; Franco, Hopenhayn and León, 2011). A variety of factors underlie these transformations, chief among them being the incorporation into the global market of the giant populations of China and India, with the consequent rise in global demand for commodities that has benefited the producer economies of Latin America. Per capita gross domestic product (GDP) growth has been such that it has impacted the monetary incomes of sectors historically situated in the poorer strata and has enlarged the middle-income population in both regions. Traditionally, much of the thinking about the importance of a vibrant middle class has been devoted to gauging its effects on economic development and the consolidation of democratic societies (Easterly, 2001; Easterly, Ritzen and Woolcock, 2006).

Distributional trends in the more developed countries over the two closing decades of the last century foreshadowed some of the issues driving the concern with studying the social structure at the present time. Rising inequality, especially in the Anglo-Saxon countries, raised new questions about the depth of the changes that were occurring. In the United States, for example, the debate about whether there was an incipient trend towards the disappearance of the middle class began, quite vigorously, as early as the mid-1980s (Thurow, 1984; Rosenthal, 1985; Blackburn and Bloom, 1985; Bradbury, 1986; Horrigan and Haugen, 1988). The subject remains topical in the central countries, with a strong impetus given to research into income polarization (Pressman, 2007; Atkinson and Brandolini, 2011). In addition, the international crisis that began in 2007 and its effects on employment and income, especially in the northern hemisphere, have reactivated concern about worsening distribution and its social impact.

In this context, it is important to stress the relevance of analysing what has happened to the social structure in Argentina. For much of the last century, the country had a vigorous middle class, a high degree of upward social mobility and low levels of inequity, giving rise at an early stage (by the standards of Latin America generally) to high levels of social integration. This began to change in the mid-1970s with the onset of a stage marked by a persistent decline in the living standards of the middle- and lower-income sectors (with the exception of some short subperiods), culminating in late 2001 with unemployment of $25 \%$ and over half the population living in poverty. Since then, there has been a shift in tendency that has proved lasting. It is clearly of interest, then, to learn whether and how the remarkable increase in GDP in the first decade of this century led to a reorganization of the social structure and, if this happened, what its scale and particular characteristics were.

The aim of this article is to use different approaches and methodologies from economics and sociology to document the evolution of the social structure in Greater Buenos Aires ${ }^{1}$ from the mid-1970s until 2010. The purpose of the research was to provide a long-term overview of the size of the social classes and to evaluate the determinants of membership in each of them between the beginning and end of the period. The workings of the labour market were specifically addressed.

The article is organized into five sections. Section II sets out some of the theoretical and methodological background of most relevance to the aims of the research, the methods of analysis used in this study and the characteristics of the data source employed. Section III presents the results of the stratification criteria used and the distributional situation during the period under review, before going on to analyse the labour market. Section IV discusses the workings and broad characteristics of the labour market. Lastly, section V offers conclusions.

\footnotetext{
1 The country's largest conurbation, containing about $30 \%$ of the total population and $40 \%$ of the total urban population.
} 


\section{II}

\section{Methodology}

\section{Background}

The study of the systems organizing modern societies has always been inseparably linked to people's employment relations, so that the classification systems developed have been based on certain job characteristics, the construction of occupational scales, or both. Sociological theory, whether in the variants that draw more on Marxist ideas (Wright, 1997 and 2009) or on Weberian thought (Erikson and Goldthorpe, 1992; Goldthorpe and McKnight, 2006), has routinely set out to conceptualize national social structures by examining the particular distribution of individuals in the world of work. Whether the emphasis is on membership of a social class (or group) or on the status (prestige) enjoyed by individuals as structuring elements of the social order and determinants of power relationships, people's occupations were inevitably the empirical variable taken. ${ }^{2}$

While this sociological tradition remains the dominant conception in the specialist literature, it has been subjected to other analytical approaches because of the growing heterogeneity that now seems to characterize occupational strata or groups, something that severely limits the usefulness of these groupings in adequately explaining social conduct or behaviour such as voting decisions, consumption patterns and the spatial distribution of population. Underlying these observations is what has been called "the end of the wage-earning society" (Rosanvallon, 1995; Castel, 1997). The crisis of the labour market as a mechanism for social integration in modern societies has not only excluded people from employment status (especially the traditional status of the full-time wage earner) but has increased the frequency of movement between the different social states (wage employment, non-wage employment, unemployment, inactivity) in a way that has made households' social status and incomes more unstable. Against this background, emphasis has been laid on the undesirability of using discrete variables for social stratification, instead of which sliding scales taking account of individuals' and households' resource

\footnotetext{
2 A review of the main contributions to the study of Latin American
} social structures can be found in Filgueira (2007). (or asset) endowments have increasingly been used to determine their position in the social structure (Prandy, 1990; Gershuny and Yee Kan, 2006; among others).

From the perspective of economic theory, conversely, the focus has been on monetary incomes as the independent variable for determining social groups and classes. The method traditionally used has been to define a priori the population size of the strata to be considered, before going on to evaluate the share of each group as thus defined in the mass of total incomes (Levy, 1988; Solimano, 2009). The lower class usually includes those in the bottom deciles of the income distribution, while the high class is composed of those at the top of the distribution. What is left over is defined as the middle class, which thus generally ranges from $40 \%$ to $60 \%$ of the population. By the same logic, thresholds have been set with reference to the poverty line, especially to define the high class (Atkinson, 2008; Eisenhauer, 2008). Whatever the rationale behind this kind of demarcation of social groups, clearly one of the main limitations of this approach is that it is not sensitive to changes in the size of social classes.

In view of this, a degree of consensus has formed around the alternative classification of the population into fixed-income strata or intervals. Thus, intertemporal comparison of population groups so defined will reflect changes in the size of their membership. Absolute limits have been used, especially for developing countries (Banerjee and Duflo, 2008), but the predominant tendency has been to set an income interval whose upper and lower bounds are fixed with reference to a central tendency statistic for income distribution, usually the median (Thurow, 1987; Birdsall, Graham and Pettinato, 2000; Foster and Wolfson, 2010). Sometimes the two approaches have been combined, with an absolute lower bound and a relative upper bound being taken (Birdsall, 2010). Although the main advantage of this approach is its sensitivity when it comes to computing increases or decreases in the size of social groups, it is subject to certain caveats, since such changes will be partly a result of the boundaries of whatever interval has been chosen.

Meanwhile, the question of what has been happening to the middle class has provided the motivation for the development of a family of distribution indicators based on the concept of polarization (Esteban and Ray, 1994; 
Duclos, Esteban and Ray, 2004; Foster and Wolfson, 2010). The central idea is that income polarization occurs as the result of two forces: identification with or closeness to the group belonged to, and alienation or differentiation vis-à-vis others. By contrast with the two previous approaches, the income bounds determining membership of each group, and the number of members, will vary over time. The result is a synthetic indicator that can be used to quantify the degree to which the middle part of the income distribution is shrinking or expanding.

In summary, sociological studies of social structure and those conducted from an economic perspective are based on different methodological traditions, but are closely related. In general, a particular ranking based on individuals' occupational characteristics or employment relations usually ties in closely with the current distributional situation in society. Indeed, it is routine to validate whatever stratification systems are chosen by their explanatory power vis-à-vis income dispersion. The two approaches are thus complementary, and their combined contributions seems to be increasingly necessary to a better understanding of the evolving physiognomy of modern societies. This article makes use of five indicators (three derived from economics and two more closely aligned with the sociological outlook), detailed in the following subsection, with a view to making a contribution in this area.

\section{Methods and data sources}

The study made use of the three economic approaches just mentioned (strata fixed by the number of members, income interval relative to the median and synthetic polarization indicator) for the explicit purpose of ascertaining what they can bring to an understanding of changes in the social structure of Argentina.

People were divided into social classes by their position in the income distribution as follows: low class (deciles 1 and 2), middle class (deciles 3 to 8 ) and high class (deciles 9 and 10). The interval defining the middle class relative to median income was 0.75 to 1.5 . Those below 0.75 and over 1.5 were placed in the low and high classes, respectively. Lastly, the polarization index employed was the one proposed by Foster and Wolfson (2010):

$$
(T-G) \mu / m
$$

where $\mu$ and $m$ are average and median per capita family income respectively, $G$ is the Gini coefficient and $T$ is the ratio between the average distance from the median of those above it and those below it. Given that $(T-G)$ is equal to the Gini coefficient between the upper and lower halves of the distribution, minus weighted intragroup inequality, it follows that the greater the inequality between the two groups (upper and lower halves), the higher both inequality and polarization will tend to be. Conversely, greater intragroup inequality (keeping a fixed distance between those above and below the median) means higher inequality but lower polarization.

This was complemented by a further two criteria for demarcating social groups based, respectively, on individuals' educational attainments and occupational status. Education has historically proved to be one of the main mechanisms for upward social movement and remains a powerful predictor of incomes. Consequently, it is relevant to compare changes in the distributional structure with alterations in the educational level of the population. To this end, three classes were constructed by the highest educational level attained: a low class (up to complete primary), a middle class (up to complete secondary) and a high class (incomplete or complete higher education).

As regards the second complementary criterion, occupational status, its relevance derives, as noted in the previous subsection, from the postulates of the sociological tradition of social class analysis. In addition, emphasis has increasingly been laid on the importance of the "employment stability" dimension as one of the most consistent determinants of people's position in the social structure (Goldthorpe and McKnight, 2006). The research used a combination of the idea of informal employment and educational level. This choice was based precisely on the way these tied in with employment instability. The idea of informal working serves to characterize a certain specificity of labour markets in developing countries. ${ }^{3}$ In the absence of general social protection mechanisms in these economies, informal (low-productivity) jobs are usually the method whereby a quite substantial proportion of people earn their living. Thus, informality is associated with unstable employment paths involving high turnover between economic activity (employment and unemployment) and inactivity. Furthermore, informal workers' incomes are different to those of formal workers, being lower. This earnings penalty, which implies a segmented labour market, may result in membership of a particular social class.

\footnotetext{
3 The original perspective was provided by the International Labour Organization in the early 1970s (ILO, 1972) and has recently been updated (Hussmanns, 2004).
} 
With the categorization used, people can be classified into the economically active and inactive, with the former being further subdivided into the employed and the unemployed. The grouping arrived at was as follows: the low class (employees not registered with the social security system, ${ }^{4}$ domestic service workers, the unemployed, the inactive and, where appropriate, beneficiaries of job creation schemes), ${ }^{5}$ the middle class (own-account workers with up to incomplete university education and registered workers of a similar educational level) and the high class (employers, professional ownaccount workers and registered employees with complete higher education). To focus attention on households with a greater dependence on the labour market, the universe of analysis was composed of household heads aged between 30 and 59, a central age range encompassing those who can be expected to be economically active.

4 Under Argentine law, wage employment is understood as an open-ended working relationship that does not require any specific contract to be signed between employer and worker. Although there are exceptions to this general rule, they have to be duly justified. Consequently, the employees who enjoy most stability are those in jobs registered by their employers with the social security system. Employees in unregistered jobs lack the protection provided by national employment contract law, some of whose sections provide for protection against dismissal, union representation and coverage by collective labour agreements.

5 Various job creation schemes have been implemented since 2001, with participants providing labour in return for benefits.
The statistical data source used was the Permanent Household Survey (EPH) prepared by the National Institute of Statistics and Censuses (INDEC). The EPH is conducted in the main cities of the country and covers about $70 \%$ of the total urban population. Its geographical coverage has been expanding since 1974, the year it began. Because the present study analyses events since that year, only information from Greater Buenos Aires could be used. From 1974 to 2003, the EPH was a non-continuous survey carried out twice a year, in May and October. It underwent a major change in the latter year; in terms of fieldwork, it became a continuous survey producing quarterly estimates for some variables and half-yearly ones for others. In addition, changes were made to the questionnaire that restricted data comparability for certain categories of analysis. It is possible to analyse changes over time, however, as there is a period that is common, or might reasonably be considered common, to both survey methods: the second quarter of 2003. The last noncontinuous survey round was held in May. The decision was taken not to carry out the adjustment for this article, however, as correcting the estimates from 2003 onward by the application of a "splicing coefficient" entails a reduction of some $7 \%$ to $8 \%$ in the estimates, which does not alter the essential results. Furthermore, there are other methodological issues with this variant.

The income variables to be used were per capita family income and monthly earnings from the main occupation.

\section{III}

\section{Distribution and the social structure}

\section{The distributional situation and income polarization}

The evolution of inequality in income distribution over the past three and a half decades took the form of an inverted U. ${ }^{6}$ There was a marked distributional deterioration during the period from 1974 to 2001, with the Gini coefficient rising by about $50 \%$ between the two years, from 0.353 to 0.531 (see table 1). Following the convertibility crisis

\footnotetext{
6 It should be stressed that these developments bear no resemblance whatsoever to Kuznets' thesis that income distribution tends to be less equitable in the early stages of growth and only later becomes more equal. Argentina is an example of the opposite: greater/lower output has usually been accompanied by lower/greater inequity.
}

of late 2001 and the subsequent drop of about $30 \%$ in real incomes because of the devaluation implemented in early 2002, a vigorous process of distributional improvement began in 2003, with the Gini index falling by somewhat over $20 \%$, from 0.537 to 0.431 . Nonetheless, the degree of inequity was still higher in 2010 than it had been in 1974.7 A similar situation of deteriorating distribution during the last quarter of the twentieth century and subsequent progress towards equity can be seen in the evolution of the ratio between average and median incomes (see table 1).

\footnotetext{
7 Regarding the potential comparability of data, see the "Methods and data source" subsection.
} 
Distribution indicatorsa in Greater Buenos Aires, 1974-2010

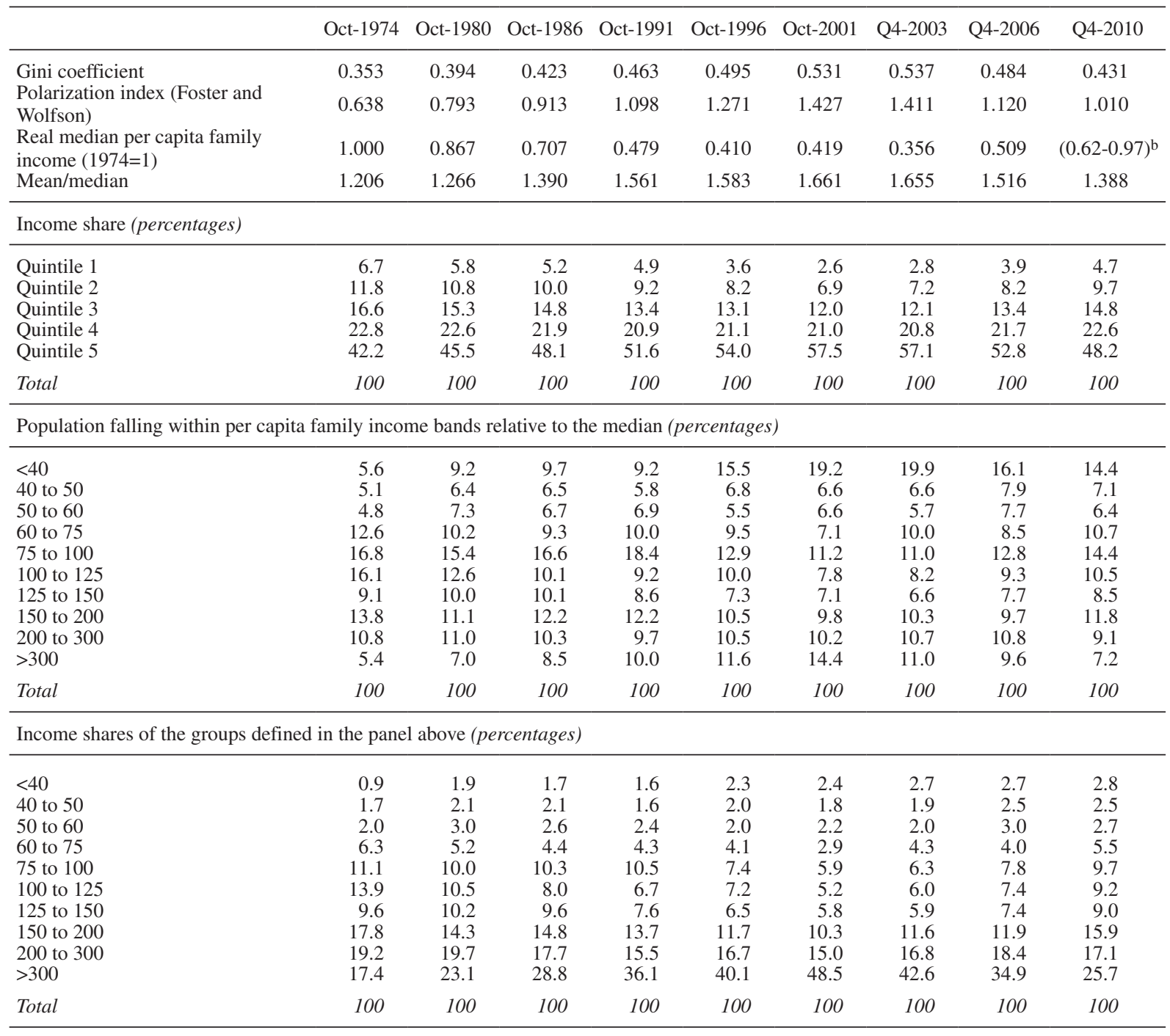

Source: prepared by the author on the basis of data from the Permanent Household Survey (EPH).

Note: The EPH data gathering methodology was altered in 2003. Various methods of splicing the data series from before and after that date can be used to deal with this. However, correcting the estimates from 2003 onward, when a "splicing coefficient" is applied, entails an adjustment of some $7 \%$ or $8 \%$. As it does not alter the primary results, the decision was taken to dispense with this variant, with which there are methodological issues.

a All distribution estimates were based on per capita family income.

b Alterations in the method of measuring the consumer price index in 2007 mean that values prior and subsequent to that year are not directly comparable. For this reason, two estimates were made, and from these it can be concluded that the value of the concept of interest falls within the interval reported.

Polarization, which, as discussed earlier, is related to inequality but is not identical with it, followed a similar pattern. It will be recalled that this phenomenon reflects an accentuation of the extremes (top and bottom) of the income distribution, so that greater polarization directly squeezes those in the middle part of the distribution. From the mid-1970s until the early twenty-first century, there was a pronounced and steady increase in polarization, 
outstripping even the distributional deterioration already discussed (see table 1). Even by 1996, the degree of polarization in the income distribution was twice what it had been in 1974, while the inequity coefficient declined by about $40 \%$ over the same period. The trend of this indicator went clearly into reverse from 2003 and for the rest of the decade. As with the Gini coefficient, however, this reversal from 2003 was not enough to make up for the cumulative deterioration of the earlier phase.

The discrepancy between the change in the Gini coefficient and the situation revealed by analysis of the degree of income polarization suggests that there were substantial changes in the social structure. This approach thus provides a more sensitive way of capturing the consolidation of groups composed of individuals sharing common attributes, i.e., groups that are reasonably homogeneous in their composition. Table 1 provides further information to justify this claim, and it can be appreciated that the increase in income concentration and polarization occurred simultaneously with a cumulative drop in real per capita incomes totalling almost $60 \%$ between 1974 and 2001. A further piece of information reflecting the combined effects of the drop in real household incomes and the worsening distribution is that the proportion of households with incomes below $40 \%$ of the average per capita family income value virtually quadrupled to $19 \%$ between 1974 and 2001, while the proportion with incomes exceeding that value by over $300 \%$ almost tripled from $5.4 \%$ to $14.4 \%$. Again, when the share of income appropriated by each income stratum is considered, it can be concluded that the bulk of the poor ended that quarter century even poorer, while the rich (whose number also increased) appropriated more resources (see the last panel of table 1). These trends were reversed in the period of expansion from 2003 to 2010 , albeit to varying degrees in the different social groups. The following section addresses this.

\section{Changes in the social structure}

It will be recalled that the study employed five criteria to measure these social groups: (i) groups with a numerically constant membership defined by their position in the income distribution; (ii) classes delimited by the position of income recipients relative to a central tendency statistic for income distribution; (iii) a derivation of the first two, taking the income share of social groups defined by a fixed income interval; (iv) taking the education level of the household head; and (v) taking the employment position of household heads of working age. (i) Delimitation by income quantiles

Using this measurement criterion, it was found that the low and middle classes (in that order) experienced a substantial drop in their income shares in the final quarter of the last century, whereas in the seven-year period beginning in 2003 they were able to recover much of that share. The low class, comprising the poorest $20 \%$ of the population, underwent a dramatic reduction in income share of about $60 \%$ between 1974 and 2001 (from $6.7 \%$ to $2.6 \%$, see table 2). The middle class, comprising the $60 \%$ of the population belonging to the second, third and fourth quintiles, also saw its income share decline, albeit to the much lesser extent of just over $20 \%$ (from $51.1 \%$ to $39.9 \%$ ). Consequently, and strikingly, the income distribution share of the high class, comprising the wealthiest $20 \%$, rose by some $35 \%$ (from $42.2 \%$ to $57.5 \%$ ). These trends were reversed over the following stage, from 2003 to 2010 , although not to the extent of restoring the situation of the mid-1970s. The recovery was greatest for the low class. If table 2 is examined again, it can be seen that the share of the lower stratum increased by about $70 \%$ (from $2.8 \%$ to $4.7 \%$ ), while that of the middle swathe rose by some $18 \%$ (from $40.1 \%$ to $47.1 \%$ ). The share of resources going to the high class accordingly fell by some $16 \%$ (from $57.1 \%$ to $48.2 \%)$. A review of the figures shows that the strength and persistence of this process of resource reallocation was unparalleled in Argentine economic history since at least the mid-1970s.

Between the beginning and end of the extended period (1974 to 2010), however, the total income share of the members of the high class increased, so that by the end of the first decade of the twenty-first century they were wealthier than they had been 36 years earlier. Similarly, the poorest still had less in the way of monetary resources than in 1974. Lastly, the middle class had not been restored to its income share of that period either, although of all three classes it came closest.

It is worth noting that these adjustments between social classes closely track the Gini coefficient (whose characteristic is that it is more sensitive to changes in the middle part of the distribution), but diverge more from the path of income polarization, which, it will be recalled, was $60 \%$ greater in 2010 than it had been in 1974. In other words, the distributional improvement in the first decade of the twenty-first century took the form of a marked recovery of incomes in the middle sector and, albeit to a lesser degree, in the low class. 
The social structure in Greater Buenos Aires, 1974-2010

(Various approaches)

Oct-1974 Oct-1980 Oct-1986 Oct-1991 Oct-1996 Oct-2001 Q4-2003 Q4-2006 Q4-2010

Income share (by income quantile of which member)

\begin{tabular}{|c|c|c|c|c|c|c|c|c|c|}
\hline Low class (bottom 20\%) & 6.7 & 5.8 & 5.2 & 4.9 & 3.6 & 2.6 & 2.8 & 3.9 & 4.7 \\
\hline Middle class (middle $60 \%$ ) & 51.1 & 48.9 & 46.7 & 43.5 & 42.4 & 39.9 & 40.1 & 43.3 & 47.1 \\
\hline High class (top 20\%) & 42.2 & 45.4 & 48.1 & 51.6 & 54.0 & 57.5 & 57.1 & 52.8 & 48.2 \\
\hline Total & 100 & 100 & 100 & 100 & 100 & 100 & 100 & 100 & 100 \\
\hline
\end{tabular}

By position in the income distribution (relative to the median)

\begin{tabular}{lrrrrrrrrr}
\hline Low class: below 75\% & 28.1 & 33.0 & 32.2 & 32.0 & 37.3 & 39.5 & 42.2 & 40.1 & 38.5 \\
Middle class: between 75\% and 150\% & 42.0 & 37.9 & 36.8 & 36.2 & 30.2 & 26.1 & 25.8 & 29.8 & 33.4 \\
High class: over 150\% & 29.9 & 29.1 & 31.0 & 31.8 & 32.6 & 34.5 & 32.0 & 30.1 & 28.1 \\
Total & 100 & 100 & 100 & 100 & 100 & 100 & 100 & 100 & 100 \\
\hline
\end{tabular}

Income share (of groups defined by position in the income distribution relative to the median)

\begin{tabular}{|c|c|c|c|c|c|c|c|c|c|}
\hline Low class: below $75 \%$ & 11.0 & 12.2 & 10.8 & 9.9 & 10.4 & 9.2 & 11.0 & 12.2 & 13.5 \\
\hline Middle class: between $75 \%$ and $150 \%$ & 34.6 & 30.7 & 27.9 & 24.7 & 21.1 & 16.9 & 18.1 & 22.6 & 27.9 \\
\hline High class: over $150 \%$ & 54.5 & 57.1 & 61.3 & 65.3 & 68.5 & 73.9 & 70.9 & 65.2 & 58.6 \\
\hline Total & 100 & 100 & 100 & 100 & 100 & 100 & 100 & 100 & 100 \\
\hline
\end{tabular}

By educational level of household head

\begin{tabular}{|c|c|c|c|c|c|c|c|c|c|}
\hline Low class: up to complete primary & 64.1 & 62.5 & 51.2 & 48.2 & 42.8 & 40.0 & 37.7 & 34.7 & 30.5 \\
\hline $\begin{array}{l}\text { Middle class: secondary (incomplete } \\
\text { and complete) }\end{array}$ & 26.2 & 25.5 & 33.0 & 34.4 & 35.5 & 35.7 & 35.6 & 37.8 & 37.1 \\
\hline $\begin{array}{l}\text { High class: higher (complete and } \\
\text { incomplete) }\end{array}$ & 9.7 & 12.0 & 15.8 & 17.5 & 21.7 & 24.3 & 26.6 & 27.5 & 32.3 \\
\hline Total & 100 & 100 & 100 & 100 & 100 & 100 & 100 & 100 & 100 \\
\hline \multicolumn{10}{|c|}{ By instability of employment (household heads aged between 30 and 59) } \\
\hline Low class: employees, unstable & 19.0 & 20.7 & 20.9 & 25.9 & 34.4 & 37.6 & 37.1 & 34.6 & 30.1 \\
\hline Middle class: stable, medium grade & 70.1 & 67.1 & 65.4 & 59.4 & 50.1 & 46.3 & 45.9 & 47.0 & 49.5 \\
\hline High class: stable, higher grade & 10.9 & 12.2 & 13.8 & 14.6 & 15.5 & 16.1 & 17.1 & 18.4 & 20.4 \\
\hline Total & 100 & 100 & 100 & 100 & 100 & 100 & 100 & 100 & 100 \\
\hline
\end{tabular}

Source: prepared by the author on the basis of data from the Permanent Household Survey (EPH).

(ii) Social classes by income interval relative to the median

When social classes are defined by an income gap from the median, ${ }^{8}$ alterations in their size over the period studied reveal a situation that, while consistent overall with the two phases that have been identified, 1974 to 2001 and 2003 to 2010 , provides additional information that is helpful in categorizing the kind of transformation undergone by the social structure of Argentina.

8 It will be recalled that the delimitation used in this study was $<75$; 75 to 150 ; and $>150$.
Using this demarcation, it can be seen that the size of the low class increased by about $40 \%$ between 1974 and 2001 , from $28.1 \%$ of the population to $39.5 \%$ (see table 2). In other words, households that were formerly in the higher social strata, and particularly the middle ones, entered this social class. Indeed, one peculiarity of this process of downward social mobility in the income distribution was that it was accompanied by a sharp contraction of the middle class, which shrank by somewhat over $35 \%$ (from $42.0 \%$ to $26.1 \%$ of the total). This figure is a stark reflection of the dissolution of the middle class in Argentine society already referred to by numerous earlier studies. It should be stressed that the 
thinning of the middle strata mainly took place during the last decade of the twentieth century. The middle class had accounted for $37.9 \%$ of the population in 1980 ; by 1991, the figure was $36.2 \%$.

Not all the reduction in the middle class went to swell the lowest stratum of society. In fact, the middle stratum of the population shrank by more than the low class grew, and the size of the high class increased accordingly. Thus, this social group expanded by $46 \%$, with its share of the population rising from $29.9 \%$ in 1974 to $34.5 \%$ in 2001 . Taken together, this evidence illustrates the kind of income polarization experienced in Argentina, characterized by rising shares of the population in the social groups at the top and bottom of the income distribution. Similar processes have been documented for other economies, examples being the United States and the United Kingdom in the period covering the 1980s and the 1990s (Jenkins, 1995; Burkhauser and others, 1999).

At this point, a methodological observation should be made to put the findings just discussed into perspective. The approach used here to demarcate the three social classes is distributional, and consequently refers to the position occupied by earners in the per capita family income classification. It says nothing, on the other hand, about whether needs are being met or about the level of consumption these relative positions entail for those in them. Thus, growth or contraction in the membership of the lower, middle and high classes has coincided with changes in the absolute poverty or wealth of each of them. When this information is incorporated, it needs to be appreciated that the increase in the size of the low class was also accompanied by a decline in this group's living standards, as measured by the purchasing power of incomes (see table 1).

Partly counteracting this process, in the phase of improving distribution between 2003 and 2010 the low class shrank by about $10 \%$, from $42.2 \%$ to $38.5 \%$ of the total. The greatest change, though, was in the middle layers of society, whose membership increased by $30 \%$ from $25.8 \%$ of the population in 2003 to $33.4 \%$ in 2010 . Consequently, the high class shrank by about $15 \%$, from $32.0 \%$ to $28.1 \%$, between the beginning and end of this seven-year period (see table 2).

The end result of developments in the social classes as variable units supports a view of Argentine society as being still affected by a high degree of social segmentation, something that is also consistent with the income polarization results. The growth in the middle class was a remarkable development, however, as virtually $8 \%$ of the population entered its ranks, with half (4 percentage points) having experienced what must be considered upward mobility (from the low class) while as many again came from the top segment. The latter movement seems to have been due to the changing distribution in the period together with the rising purchasing power of incomes, as the median per capita family income increased by $43 \%$ in real terms between 2003 and 2006.

As a corollary of the trends documented for the three main social classes, after some four decades the high class ended up at virtually the same level, while the share of the middle class was down by 9 percentage points, from $42.0 \%$ to $33.4 \%$, and the low class had gained the same amount, with its share rising from about $28.1 \%$ to $38.5 \%$.

\section{(iii) The income shares of the social classes as defined above}

The time has now come to introduce the results of the third measurement approach, which, as already noted, can be used to gauge income appropriation by the social groups, defined on this occasion by taking variable boundaries. In this case, the distances from the median income settled upon to demarcate the social classes in (ii) will be retained and the income appropriated by each will be assessed.

It can be established that in the subperiod from 1974 to 2001, the income share of the low class (whose size increased) fell dramatically, by some $35 \%$ (see table 2 ). To put it differently, not only did the membership of the most disadvantaged group increase, but those in it received a smaller share of income as a class, meaning that in per capita terms they were poorer than they had been 25 years before. The middle class, which contracted greatly, was also affected by a sharp reduction (of over 50\%) in its income share. Indeed, this shrank by more than that class's membership, confirming that, as happened with the members of the low class, those of the middle class had lower incomes on average in 2001 than in 1974. Not only was there downward mobility in the period, but those who succeeded in remaining within the middle stratum lost income. Only the high class was able to achieve the virtuous double of increasing its membership while increasing its income share by even more-some $50 \%$.

In the following period, 2003 to 2010 , the situation was reversed, albeit only in part, and followed the pattern already discussed. The improvement was greatest for the middle class, whose income share grew by about $50 \%$, and somewhat lesser for the lowest class, with a figure of about $23 \%$. The income share of the high class, on the other hand, fell by $16 \%$, which was slightly greater than the decline in its membership over the same period. 
This provides important evidence that, by contrast with earlier stages, those remaining in the best-off sector of society experienced a reduction in the income available to them as a class.

Between the beginning and end of the extended period of almost four decades starting in 1974, the situation was still far from the level achieved in 1974. By late 2010, the high class had a larger income share than in the mid-1970s. The low class had not recovered the share of resources available to it then, while the middle class was in deficit by about $20 \%$.

\section{(iv) The educational level of household heads}

As was to be expected, the educational level of household heads improved steadily and indeed substantially over the whole period. Whereas in 1974 about two in every three household heads had complete basic schooling or less, having never even started secondary school, by 2010 this group accounted for only $30.5 \%$ of the total (see table 2). Similarly, the number who had commenced higher education more than tripled between 1974 and 2010. Taken together with the social structure just described, these developments suggest a growing mismatch between people's educational attainment and their position in the social structure. This gap can be seen both in the trends of the different indicators of distribution and in those of occupational instability (see point (v) below). In other words, the shrinking of the middle class and the swelling of the low class during the 1974-2001 period, and the reversal of both processes between 2003 and 2010, took place in a context of sustained improvement in the educational level of the population. This characteristic, the devaluation of educational credentials, seems to have become a rather particular feature of the path followed by Argentine society. By contrast with what had happened in the past, educational attainment did not fully play its role in protecting incomes and employment quality during phases of deteriorating economic and social conditions. Its capacity for restoring people to similar positions in the social structure during upturns was also reduced.

\section{(v) The employment position of household heads in mid-life}

Some $70 \%$ of the population live in households whose heads are aged between 30 and 59. In addition, these household members provide about $70 \%$ of total earnings (see table 4). These two facts warrant a closer look at their participation in economic activity.

The evolution of the social structure thus demarcated very closely matches the first three approaches used. The proportion of households whose heads were working in unstable occupations practically doubled between 1974 and 2001, while the intermediate segment of families with heads in stable jobs fell by about $25 \%$ (see table 2). As a result of these two developments, the group of households with heads in stable higher-grade work increased its share from $10.9 \%$ to $16.1 \%$. The evolution of income distribution (increased concentration) and growing polarization (the shrinking of the middle class) clearly have a connection with the rising instability of employment among household heads. It can also be seen that in the seven-year period beginning in 2003, improved distribution, reduced polarization and the expansion of the middle class were accompanied by an increase in the instability of household heads' occupations.

\section{IV}

\section{The workings of the labour market 9}

\section{General characteristics}

There is a great deal of evidence that the shifting workings of the labour market gave rise to the changes in the social structure that have been discussed. Between 1974 and 2001, unemployment and informal working rose sharply, while the employment rate fell (see table 3). Again, in the 2003-2010 period, both open unemployment and informality declined while the employment rate increased substantially.
It is now time for a more detailed analysis, focusing on the economic participation of household heads. ${ }^{10}$

\footnotetext{
9 The references to social classes in what follows are based on the stratification carried out using criterion (ii): social classes by income interval relative to the median.

10 It has already been mentioned that the occupational characteristics of household heads belonging to each of the three social classes identified provide the information needed to assess the deeper causes of changes in the social structure. Households' monetary income derives essentially from the work of their members, and particularly their heads (see table 4).
} 
TABLE 3

The labour market in Greater Buenos Aires, 1974-2010

(Percentages)

\begin{tabular}{|c|c|c|c|c|c|c|c|c|c|}
\hline & Oct-1974 & Oct-1980 & Oct-1986 & Oct-1991 & Oct-1996 & Oct-2001 & Q4-2003 & Q4-2006 & Q4-2010 \\
\hline Activity rate & 49.1 & 48.3 & 49.0 & 49.7 & 53.8 & 52.8 & 57.7 & 57.8 & 56.6 \\
\hline $\begin{array}{l}\text { Activity rate without job } \\
\text { creation scheme beneficiaries }\end{array}$ & & & & & & 52.2 & 54.9 & 57.0 & 56.2 \\
\hline Employment rate & 47.9 & 47.4 & 46.8 & 47.1 & 43.7 & 42.6 & 48.9 & 52.4 & 52.1 \\
\hline $\begin{array}{l}\text { Employment rate without job } \\
\text { creation scheme beneficiaries }\end{array}$ & & & & & & 42.1 & 46.0 & 51.5 & 51.6 \\
\hline Unemployment rate & 2.4 & 2.2 & 4.5 & 5.3 & 18.8 & 19.3 & 15.5 & 9.7 & 8.0 \\
\hline $\begin{array}{l}\text { Unemployment rate without job } \\
\text { creation scheme beneficiaries }\end{array}$ & & & & & & 19.5 & 16.3 & 9.9 & 8.1 \\
\hline Informal jobs & 37.7 & 38.0 & 42.0 & 47.0 & 46.9 & 48.6 & 55.3 & 51.2 & 42.1 \\
\hline $\begin{array}{l}\text { Informal jobs without job } \\
\text { creation scheme beneficiaries }\end{array}$ & & & & & & 47.9 & 52.5 & 50.4 & 41.6 \\
\hline $\begin{array}{l}\text { Unregistered employees }{ }^{\mathrm{a}} \text { as } \\
\text { share of all employees }\end{array}$ & 19.0 & 17.1 & 21.1 & 30.0 & 33.3 & 33.5 & 39.1 & 36.4 & 28.1 \\
\hline
\end{tabular}

Source: prepared by the author on the basis of data from the Permanent Household Survey (EPH).

a Excludes domestic service and job creation scheme beneficiaries.

TABLE 4

Structure of households and family incomes in Greater Buenos Aires, 1974-2010 (Selected years)

\begin{tabular}{|c|c|c|c|c|c|c|}
\hline & Oct-1974 & Oct-1986 & Oct-1996 & Q4-2003 & Q4-2006 & Q4-2010 \\
\hline \multicolumn{7}{|l|}{ Percentage of households } \\
\hline Households with heads aged under 30 & 11.7 & 9.8 & 9.9 & 9.9 & 9.6 & 8.6 \\
\hline Households with heads aged between 30 and 59 & 60.3 & 57.4 & 58.5 & 58.6 & 58.2 & 59.0 \\
\hline Households with heads aged over 59 & 28.0 & 32.8 & 31.5 & 31.6 & 32.2 & 32.5 \\
\hline \multicolumn{7}{|l|}{ Percentage of population } \\
\hline Households with heads aged under 30 & 10.8 & 9.6 & 8.7 & 8.9 & 8.3 & 7.8 \\
\hline Households with heads aged between 30 and 59 & 68.5 & 67.7 & 69.1 & 68.5 & 67.9 & 68.0 \\
\hline Households with heads aged over 59 & 20.7 & 22.7 & 22.2 & 22.7 & 23.8 & 24.2 \\
\hline Total & 100 & 100 & 100 & 100 & 100 & 100 \\
\hline \multicolumn{7}{|c|}{ Percentage of total family income from main occupation of family members } \\
\hline Households with heads aged under 30 & 91.6 & 88.2 & 83.9 & 83.3 & 77.8 & 83.6 \\
\hline Households with heads aged between 30 and 59 & 84.1 & 86.7 & 86.3 & 77.1 & 82.7 & 87.4 \\
\hline Households with heads aged over 59 & 41.4 & 40.8 & 36.0 & 46.3 & 43.2 & 45.0 \\
\hline \multicolumn{7}{|c|}{ Percentage of earnings contributed by head (main occupation) } \\
\hline Households with heads aged under 30 & 79.1 & 81.2 & 82.0 & 76.3 & 79.2 & 77.3 \\
\hline Households with heads aged between 30 and 59 & 77.1 & 77.6 & 75.7 & 74.4 & 68.6 & 68.3 \\
\hline Households with heads aged over 59 & 47.8 & 50.4 & 47.5 & 63.3 & 52.4 & 50.2 \\
\hline
\end{tabular}

Source: prepared by the author on the basis of data from the Permanent Household Survey (EPH). 
The first thing to highlight is the economic participation rate of this group. This is an indicator of willingness to work in a remunerated activity in the market, i.e., it is the sum of the employed and the unemployed relative to the total reference population, and its value will consequently tend to be greater in mid-life than at either end of the life cycle. For the universe taken here, consisting of household heads aged from 30 to 59 , this value can be expected to be very close to $100 \%$. Any shortfall is the result of family decisions about which members are going to participate in economic activity, and of situations in which people are more or less motivated to seek a job because of the greater or lesser likelihood of obtaining one. Between 1974 and 1996, there was a gradual reduction in inactivity among household heads, bringing their activity rate up from $91 \%$ to $94 \%$, while from 2003 to 2010 the trend reversed and the rate fell from $96 \%$ to $92 \%$, or held steady at about $91 \%$ if beneficiaries of job creation schemes are treated as spuriously active (see table 5). The reasons for this change are beyond the scope of this article, but suffice to say that it could be due to the drop in real household incomes in the first period and a degree of weakness in the demand for employment in the second. Support is given to this interpretation by the fact that the economic activity rate in the low class had risen to just $85 \%$ or so by 2010 , whereas the figures were $92 \%$ in the middle class and $97 \%$ in the high class.

The trend of open unemployment provides a more detailed picture. Whereas in 1974 the unemployment rate among household heads was marginal (around 1\%), this figure increased tenfold over the next two decades, rising to about $11 \%$ by 1996 . This development was particularly felt in the low class, with unemployment rising from less than $3 \%$ in the mid-1970s to almost $25 \%$. If the seven-year period from 2003 to 2010 is taken, by contrast, it transpires that the unemployment rate was already back to single digits by 2003 and had fallen by about $50 \%$ by 2010 (it will be recalled that beneficiaries of job creation schemes are shifted from the unemployed to the employed category). The differing evolution of this indicator by social class should once again be noted. About $7 \%$ of household heads in the low class were actively seeking work, while the proportion of unemployed in the middle and high classes was about $2.7 \%$ and $1.4 \%$, respectively, in 2010 .

Where employment quality is concerned, stress should be laid on the high level of informal working (ownaccount workers, unregistered employees, domestic service and beneficiaries of job creation schemes) throughout the period; furthermore, this behaved procyclically relative to unemployment. The rate of informal employment rose from $27 \%$ to $35 \%$ between 1974 and 1996, while in the later phase, from 2003 to 2010, the combined share of all types of informal employment dropped from $46 \%$ to $36 \%$. Again, whereas growth in own-account working was the most dynamic component of informal employment between 1974 and 1986, the variable underlying the change in the share of informal working thereafter was the expansion of jobs not registered with the social security system. From the mid-1980s onward, there was little change in the employment shares of either own-account workers (ranging from $18 \%$ to $20 \%$ ) or domestic service workers (ranging from about $3 \%$ to $5 \%$ ). In the expansionary period from 2003 to 2010, the reduction in informal working among household heads was due to the relative decline of unregistered jobs, own-account working and participation in job creation schemes, in that order.

In summary, the proportion of household heads working in formal employment (defined as registered wage employment) plus employers peaked in 1974 at $63 \%$, bottomed out in 2003 at $43.1 \%$ and then rose strongly again to $52.3 \%$ in 2010 , although this was still below the mid-1970s level (see table 5).

The general pattern described was seen in all three social classes, but to differing degrees, with lack of convergence a notable characteristic. In the low class, just $30 \%$ of household heads had a formal job in 2010, whereas in the middle and high classes the figures were $55 \%$ and $70 \%$, respectively. In 1974 , on the other hand, the figures had been $55 \%, 64 \%$ and $67 \%$ for the low, middle and high classes, respectively. The fall-off was sharpest in the low class, especially between 1986 and 1996, when the share declined by over 20 percentage points, from $51 \%$ to $30 \%$.

Between 2003 and 2010, the amount of formal employment was somewhat smaller, in relative terms, in the low class: whereas the gap for this indicator between the high and low classes was 35 points in 2003 , by 2010 it had widened to $39.5 \%$. Something worth highlighting is that the degree of dispersion between classes for this indicator was much greater in 2010 than in 1974. The decline or expansion of unregistered employment, together with the evolution of unemployment, thus emerge as important determinants of changes in the social structure (see table 5). Nor can the existence of earnings gaps by occupational category and social class be overlooked (see table 6). 
TABLE 5

Employment status of household heads aged between 30 and 59 in Greater Buenos Aires, in total and by social class, 1974-2010

(Percentages)

\begin{tabular}{|c|c|c|c|c|c|c|}
\hline & Oct-1974 & Oct-1986 & Oct-1996 & Q4-2003 & Q4-2006 & Q4-2010 \\
\hline \multicolumn{7}{|l|}{ All household heads } \\
\hline Employers & 7.1 & 6.4 & 4.9 & 4.4 & 4.4 & 4.5 \\
\hline Own-account workers & 18.0 & 20.7 & 18.1 & 20.1 & 19.3 & 17.6 \\
\hline Registered employees & 55.9 & 52.0 & 42.7 & 38.7 & 41.8 & 47.8 \\
\hline Unregistered employees & 6.3 & 6.8 & 13.9 & 17.6 & 17.2 & 13.2 \\
\hline Domestic service & 2.7 & 3.6 & 3.2 & 3.7 & 5.6 & 4.6 \\
\hline Unemployed & 1.1 & 3.1 & 10.9 & 6.7 & 3.9 & 3.6 \\
\hline Inactive & 8.8 & 7.3 & 6.3 & 4.2 & 6.3 & 8.0 \\
\hline Job creation scheme beneficiaries & 0 & 0 & 0 & 4.6 & 1.5 & 0.7 \\
\hline Total & 100 & 100 & 100 & 100 & 100 & 100 \\
\hline \multicolumn{7}{|l|}{ Low-class household heads } \\
\hline Employers & 2.6 & 1.9 & 0.4 & 2.4 & 1.7 & 1.4 \\
\hline Own-account workers & 13.8 & 18.0 & 14.4 & 20.0 & 21.0 & 20.5 \\
\hline Registered employees & 52.6 & 49.4 & 30.1 & 21.5 & 25.4 & 29.3 \\
\hline Unregistered employees & 8.5 & 9.8 & 16.6 & 21.0 & 22.4 & 20.0 \\
\hline Domestic service & 5.9 & 4.7 & 4.5 & 3.8 & 8.1 & 6.5 \\
\hline Unemployed & 2.6 & 7.4 & 24.6 & 13.1 & 7.6 & 7.0 \\
\hline Inactive & 14.0 & 8.5 & 9.4 & 6.2 & 9.7 & 14.6 \\
\hline Job creation scheme beneficiaries & & & & 11.5 & 3.9 & 0.7 \\
\hline Total & 100 & 100 & 100 & 100 & 100 & 100 \\
\hline \multicolumn{7}{|l|}{ Middle-class household heads } \\
\hline Employers & 6.4 & 3.8 & 2.0 & 2.9 & 2.3 & 3.9 \\
\hline Own-account workers & 17.9 & 20.7 & 15.6 & 24.7 & 21.0 & 15.8 \\
\hline Registered employees & 57.8 & 53.8 & 48.2 & 42.2 & 43.4 & 50.9 \\
\hline Unregistered employees & 5.9 & 6.0 & 16.0 & 17.7 & 18.1 & 13.6 \\
\hline Domestic service & 2.6 & 5.4 & 3.7 & 3.2 & 6.7 & 5.0 \\
\hline Unemployed & 1.1 & 1.8 & 7.9 & 3.0 & 2.9 & 2.7 \\
\hline Inactive & 8.3 & 8.5 & 6.7 & 4.6 & 5.0 & 6.8 \\
\hline Job creation scheme beneficiaries & & & & 1.6 & 0.6 & 1.4 \\
\hline Total & 100 & 100 & 100 & 100 & 100 & 100 \\
\hline \multicolumn{7}{|l|}{ High-class household heads } \\
\hline Employers & 10.9 & 12.1 & 10.6 & 7.0 & 8.7 & 7.9 \\
\hline Own-account workers & 20.9 & 22.7 & 22.8 & 17.2 & 16.3 & 16.5 \\
\hline Registered employees & 55.8 & 52.1 & 48.2 & 51.9 & 55.7 & 62.4 \\
\hline Unregistered employees & 5.4 & 5.5 & 10.4 & 14.4 & 11.8 & 6.6 \\
\hline Domestic service & 0.8 & 1.1 & 1.7 & 3.8 & 2.4 & 2.5 \\
\hline Unemployed & 0.1 & 1.3 & 2.6 & 3.3 & 1.2 & 1.4 \\
\hline Inactive & 6.1 & 5.2 & 3.8 & 2.1 & 4.0 & 2.8 \\
\hline \multicolumn{7}{|l|}{ Job creation scheme beneficiaries } \\
\hline Total & 100 & 100 & 100 & 100 & 100 & 100 \\
\hline
\end{tabular}

Source: prepared by the author on the basis of data from the Permanent Household Survey (EPH). 
Relative earnings of household heads aged between 30 and 59 in Greater Buenos Aires, 1974-2010, in total and by social class ${ }^{a, b}$

(Percentages)

\begin{tabular}{|c|c|c|c|c|c|c|}
\hline & Oct-1974 & Oct-1986 & Oct-1996 & Q4-2003 & Q4-2006 & Q4-2010 \\
\hline \multicolumn{7}{|l|}{ All household heads } \\
\hline Employers & 158 & 232 & 237 & 188 & 188 & 168 \\
\hline Own-account workers & 104 & 103 & 97 & 78 & 74 & 77 \\
\hline Registered employees & 97 & 91 & 99 & 126 & 125 & 118 \\
\hline Unregistered employees & 70 & 67 & 72 & 78 & 73 & 66 \\
\hline Domestic service & 43 & 40 & 37 & 42 & 30 & 34 \\
\hline \multicolumn{7}{|l|}{ Low-class household heads } \\
\hline Employers & 74 & 59 & 53 & 55 & 37 & 62 \\
\hline Own-account workers & 59 & 46 & 35 & 35 & 36 & 39 \\
\hline Registered employees & 71 & 53 & 52 & 67 & 73 & 76 \\
\hline Unregistered employees & 54 & 44 & 37 & 43 & 49 & 46 \\
\hline Domestic service & 37 & 34 & 30 & 29 & 22 & 19 \\
\hline \multicolumn{7}{|c|}{ Middle-class household heads } \\
\hline Employers & 131 & 99 & 104 & 103 & 94 & 118 \\
\hline Own-account workers & 95 & 80 & 72 & 59 & 63 & 74 \\
\hline Registered employees & 89 & 72 & 72 & 92 & 104 & 103 \\
\hline Unregistered employees & 64 & 61 & 59 & 72 & 69 & 68 \\
\hline Domestic service & 44 & 39 & 34 & 46 & 31 & 42 \\
\hline \multicolumn{7}{|c|}{ High-class household heads } \\
\hline Employers & 190 & 292 & 260 & 240 & 235 & 206 \\
\hline Own-account workers & 133 & 156 & 139 & 139 & 129 & 124 \\
\hline Registered employees & 123 & 136 & 141 & 165 & 160 & 147 \\
\hline Unregistered employees & 93 & 103 & 126 & 122 & 117 & 117 \\
\hline
\end{tabular}

Source: prepared by the author on the basis of data from the Permanent Household Survey (EPH).

a Average for each year $=100$.

b Monthly earnings from the main occupation declared.

\section{The determinants of social class}

The evidence just provided suggests that changes in the employment structure and in relative earnings have acted as determinants of social class in Argentina. One way of addressing this issue more precisely is to use multinomial logistic regression analysis. These models are a variation on conventional logit estimates and are appropriate when the dependent variable comprises more than two categories, in this case the three classes: low, middle and high (base category). The universe of analysis comprised household heads aged between 30 and 59 (version 1) and the subset of employed people belonging to this group (version 2). The variables of interest were the status of household heads as employed and inactive versus unemployed (version 1) and the occupational categories of employer, registered employee, unregistered employee and domestic service worker versus that of own-account worker (version 2). The rest of the independent covariates were sex, age and age squared, educational level, household size and the number of working family members. Both versions of the model were estimated for 1974 and 2010 (see tables 7a and 7b).

In version 1 of the model, controlling for the set of variables incorporated into it, the fact of the household head having been employed made membership of the low 
class less likely. Conversely, the likelihood of forming part of the low class was not significantly different for inactive heads and unemployed heads. To a somewhat lesser degree, the same finding was obtained for the likelihood of belonging to the middle class (always relative to the high class). These two findings held good for both 1974 and 2010 (see table 7a). This highlights the fact that access to a job for the household head has historically been a powerful determinant of membership of the middle and high social classes.

With version 2, it is possible to go on to identify the effect of a particular occupational status. The model revealed that in 1974, being an unregistered worker was associated with a greater chance of belonging to the low class (see table 7b). To a lesser degree, close to the limit of statistical significance, a similar picture emerged for the likelihood of belonging to the middle class (relative to the high class). This finding confirms that there was an income penalty for employees in undeclared jobs, who were relegated to the lower social stratum. Again, the absence of a negative likelihood of belonging to the low class for employees in registered jobs reflects the fact that earnings differences between these and ownaccount workers (the omitted category in the model) were not significant at the time. This is consistent with the existence of a "quasi-formal" type of own-account work that provided incomes similar to (and in some cases even higher than) those earned by registered workers.

Estimates of the determinants of social class in Greater Buenos Aires, 1974 and 2010 (Multinomial logistic regression models)

\begin{tabular}{|c|c|c|c|c|c|c|}
\hline & \multicolumn{6}{|c|}{ Universe: all household heads aged between 30 and 59} \\
\hline & \multicolumn{3}{|c|}{ Oct-1974 } & \multicolumn{3}{|c|}{ Q4-2010 } \\
\hline \multicolumn{7}{|l|}{ Dependent variable: low class } \\
\hline Independent variables & Coefficient & Standard error & $\mathrm{P}>|\mathrm{z}|$ & Coefficient & Standard error & $\mathrm{P}>|\mathrm{z}|$ \\
\hline Male & -1.551 & 0.260 & 0.000 & -1.369 & 0.225 & 0.000 \\
\hline Age & -0.155 & 0.109 & 0.155 & -0.054 & 0.129 & 0.676 \\
\hline Age squared & 0.001 & 0.001 & 0.263 & 0.000 & 0.001 & 0.767 \\
\hline Education: up to incomplete secondary & -1.358 & 0.180 & 0.000 & -2.160 & 0.521 & 0.000 \\
\hline Education: up to incomplete higher & -3.583 & 0.309 & 0.000 & -3.597 & 0.534 & 0.000 \\
\hline Education: complete higher & -6.107 & 0.625 & 0.000 & -5.885 & 0.596 & 0.000 \\
\hline Working & -4.767 & 1.155 & 0.000 & -3.417 & 0.526 & 0.000 \\
\hline Inactive & -2.180 & 1.177 & 0.064 & -1.000 & 0.640 & 0.118 \\
\hline Number of members in household & 1.516 & 0.076 & 0.000 & 1.831 & 0.100 & 0.000 \\
\hline Number of working members in household & -2.481 & 0.144 & 0.000 & -2.354 & 0.161 & 0.000 \\
\hline Constant & 7.868 & 2.646 & 0.003 & 6.131 & 2.818 & 0.030 \\
\hline \multicolumn{7}{|l|}{ Dependent variable: middle class } \\
\hline Independent variables & Coefficient & Standard error & $\mathrm{P}>|\mathrm{z}|$ & Coefficient & Standard error & $\mathrm{P}>|\mathrm{z}|$ \\
\hline Male & -0.617 & 0.194 & 0.001 & -0.766 & 0.181 & 0.000 \\
\hline Age & -0.044 & 0.082 & 0.593 & -0.010 & 0.106 & 0.924 \\
\hline Age squared & 0.000 & 0.001 & 0.685 & 0.000 & 0.001 & 0.943 \\
\hline Education: up to incomplete secondary & -0.894 & 0.144 & 0.000 & -1.616 & 0.484 & 0.001 \\
\hline Education: up to incomplete higher & -1.746 & 0.191 & 0.000 & -2.475 & 0.490 & 0.000 \\
\hline Education: complete higher & -3.766 & 0.367 & 0.000 & -3.561 & 0.507 & 0.000 \\
\hline Working & -2.595 & 1.134 & 0.022 & -1.490 & 0.519 & 0.004 \\
\hline Inactive & -1.536 & 1.153 & 0.183 & -0.260 & 0.628 & 0.679 \\
\hline Number of members in household & 0.857 & 0.057 & 0.000 & 1.124 & 0.084 & 0.000 \\
\hline Number of working members in household & -1.137 & 0.091 & 0.000 & -1.159 & 0.129 & 0.000 \\
\hline Constant & 3.938 & 2.142 & 0.066 & 3.082 & 2.367 & 0.193 \\
\hline Observations & \multirow{3}{*}{\multicolumn{2}{|c|}{$\begin{array}{r}1991 \\
0.255\end{array}$}} & \multirow{3}{*}{\multicolumn{4}{|c|}{$\begin{array}{r}1479 \\
0.335\end{array}$}} \\
\hline Pseudo $\mathrm{R}^{2}$ & & & & & & \\
\hline Base variable: high class & & & & & & \\
\hline
\end{tabular}

Source: prepared by the author on the basis of data from the Permanent Household Survey (EPH). 
TABLE 7B

Estimates of the determinants of social class in Greater Buenos Aires, 1974 and 2010

(Multinomial logistic regression models)

Universe: working household heads aged between 30 and 59

\begin{tabular}{|c|c|c|c|c|c|c|}
\hline & \multicolumn{3}{|c|}{ Oct-1974 } & \multicolumn{3}{|c|}{ Q4-2010 } \\
\hline \multicolumn{7}{|l|}{ Dependent variable: low class } \\
\hline Independent variables & Coefficient & Standard error & $\mathrm{P}>|\mathrm{z}|$ & Coefficient & Standard error & $\mathrm{P}>|\mathrm{z}|$ \\
\hline Male & -1.184 & 0.336 & 0.000 & -0.868 & 0.290 & 0.003 \\
\hline Age & -0.161 & 0.123 & 0.192 & -0.261 & 0.150 & 0.081 \\
\hline Age squared & 0.001 & 0.001 & 0.302 & 0.003 & 0.002 & 0.101 \\
\hline Education: up to incomplete secondary & -1.318 & 0.198 & 0.000 & -1.844 & 0.596 & 0.002 \\
\hline Education: up to incomplete higher & -3.481 & 0.336 & 0.000 & -3.113 & 0.609 & 0.000 \\
\hline Education: complete higher & -6.232 & 0.731 & 0.000 & -5.601 & 0.692 & 0.000 \\
\hline Employer & -1.326 & 0.425 & 0.002 & -3.142 & 0.596 & 0.000 \\
\hline Registered employee & 0.238 & 0.225 & 0.289 & -2.301 & 0.288 & 0.000 \\
\hline Unregistered employee & 1.421 & 0.370 & 0.000 & 0.429 & 0.365 & 0.239 \\
\hline Domestic service & 3.422 & 0.592 & 0.000 & 0.733 & 0.507 & 0.148 \\
\hline Number of members in household & 1.663 & 0.084 & 0.000 & 2.147 & 0.120 & 0.000 \\
\hline Number of working members in household & -2.525 & 0.160 & 0.000 & -2.787 & 0.192 & 0.000 \\
\hline Constant & 2.156 & 2.633 & 0.413 & 7.176 & 3.238 & 0.027 \\
\hline \multicolumn{7}{|l|}{ Dependent variable: middle class } \\
\hline Independent variables & Coefficient & Standard error & $\mathrm{P}>|\mathrm{z}|$ & Coefficient & Standard error & $\mathrm{P}>|\mathrm{z}|$ \\
\hline Male & -0.267 & 0.236 & 0.258 & -0.629 & 0.212 & 0.003 \\
\hline Age & -0.057 & 0.087 & 0.513 & -0.180 & 0.116 & 0.122 \\
\hline Age squared & 0.001 & 0.001 & 0.581 & 0.002 & 0.001 & 0.138 \\
\hline Education: up to incomplete secondary & -0.843 & 0.154 & 0.000 & -1.738 & 0.538 & 0.001 \\
\hline Education: up to incomplete higher & -1.722 & 0.202 & 0.000 & -2.486 & 0.544 & 0.000 \\
\hline Education: complete higher & -3.633 & 0.382 & 0.000 & -3.683 & 0.562 & 0.000 \\
\hline Employer & -0.573 & 0.256 & 0.025 & -1.303 & 0.411 & 0.002 \\
\hline Registered employee & 0.162 & 0.159 & 0.306 & -0.735 & 0.228 & 0.001 \\
\hline Unregistered employee & 0.602 & 0.280 & 0.032 & 0.577 & 0.320 & 0.072 \\
\hline Domestic service & 1.830 & 0.531 & 0.001 & 0.363 & 0.453 & 0.424 \\
\hline Number of members in household & 0.923 & 0.062 & 0.000 & 1.297 & 0.097 & 0.000 \\
\hline Number of working members in household & -1.176 & 0.096 & 0.000 & -1.333 & 0.143 & 0.000 \\
\hline Constant & 0.969 & 1.892 & 0.609 & 5.549 & 2.532 & 0.028 \\
\hline Observations & \multirow{3}{*}{\multicolumn{2}{|c|}{$\begin{array}{r}1797 \\
0.2808\end{array}$}} & \multirow{3}{*}{\multicolumn{4}{|c|}{$\begin{array}{r}1306 \\
0.3814\end{array}$}} \\
\hline Pseudo $\mathrm{R}^{2}$ & & & & & & \\
\hline Base variable: high class & & & & & & \\
\hline
\end{tabular}

Source: prepared by the author on the basis of data from the Permanent Household Survey (EPH).

In 2010 , the situation changed and the fact of a household head working in a registered job reduced the likelihood of belonging to the low class, while being employed in a job that was not registered with the social security system did not increase it. This was because relative pay levels changed to such a degree that the fact of not having a registered job became a determinant of low class membership. The parameters estimated suggest both a widening of the earnings gap between registered and unregistered employees and a narrowing of the gap between the latter and own-account workers.

The evidence set out in the previous section documented an expansion of the unregistered workers segment in 2010 relative to the situation in the mid-1970s (see table 5). Similarly, a widening of the average pay gap between registered and unregistered employees had already taken place (see table 6). One way of ascertaining whether this outcome was due to occupational status 
or instead to other personal characteristics of wage earners is to estimate Mincerian earnings regressions (Mincer, 1974). Using least squares regression models to estimate individual earnings functions provides a way of ascertaining the average earnings difference between the formal (unregistered) and formal (registered) employees groups, after "controlling" for the effect of other characteristics of individuals and jobs usually considered to influence pay. The individual coefficients of the function correspond to different attributes that are included in the model specified and yield an earnings differential associated with that status. The dependent variable was the logarithm of the monthly wage and the independent variable of interest was employment in a job not registered with the social security system. Thus, the estimated parameter associated with this variable encapsulates a pay difference due to that attribute. The other covariates were educational level, sex, age, age squared, hours worked and sector of activity.

It can be seen that the penalty for holding an unregistered job doubled from 0.30 to 0.59 between 1974 and 2010 (see table 8). This shows that the rise of informality in the structure of Argentine employment in the twenty-first century has been accompanied by an increase in wage segmentation. As already seen, this has also affected the social structure, as the type of job a person is able to obtain has become a factor influencing social class membership.

TABLE 8

Estimates of wage determinants in Greater Buenos Aires, 1974 and 2010a (Ordinary least squares regression models)

\begin{tabular}{|c|c|c|c|c|c|c|}
\hline \multirow{2}{*}{$\begin{array}{l}\text { Dependent variable: natural logarithm of wage } \\
\text { Independent variables }\end{array}$} & \multicolumn{3}{|c|}{ Oct-1974 } & \multicolumn{3}{|c|}{ Q4-2010 } \\
\hline & Coefficient & Standard error & $\mathrm{P}>|\mathrm{z}|$ & Coefficient & Standard error & $\mathrm{P}>|z|$ \\
\hline Unregistered employee & -0.303 & 0.045 & 0.000 & -0.596 & 0.046 & 0.000 \\
\hline Age & 0.025 & 0.016 & 0.115 & 0.050 & 0.023 & 0.032 \\
\hline Age squared & 0.000 & 0.000 & 0.114 & -0.001 & 0.000 & 0.052 \\
\hline Male & 0.467 & 0.044 & 0.000 & 0.240 & 0.046 & 0.000 \\
\hline Up to complete primary & -0.406 & 0.046 & 0.000 & -0.960 & 0.094 & 0.000 \\
\hline Up to incomplete secondary & -0.221 & 0.044 & 0.000 & -0.671 & 0.051 & 0.000 \\
\hline Up to incomplete tertiary & 0.064 & 0.049 & 0.197 & -0.461 & 0.048 & 0.000 \\
\hline Sector dummies & Yes & & & Yes & & \\
\hline Hours & 0.006 & 0.001 & 0.000 & 0.011 & 0.001 & 0.000 \\
\hline Constant & 7.107 & 0.345 & 0.000 & 6.705 & 0.495 & 0.000 \\
\hline Observations & \multicolumn{2}{|c|}{1724} & \multicolumn{4}{|c|}{922} \\
\hline $\mathrm{R}^{2}$ & \multicolumn{2}{|c|}{0.310} & \multicolumn{4}{|c|}{0.503} \\
\hline
\end{tabular}

Source: prepared by the author on the basis of data from the Permanent Household Survey (EPH).

a Controlling for sample selection.

\section{$\mathrm{V}$}

\section{Conclusions}

The evolution of inequality in income distribution in Greater Buenos Aires between the mid-1970s and the end of the first decade of the twenty-first century hinted at far-reaching changes in the social structure. Meanwhile, measuring income polarization provided confirmation that the evolution of the middle class was one of the most prominent features of these changes. Another simultaneous development, furthermore, were large fluctuations in real per capita incomes throughout the period. This situation was confirmed by the different social stratification criteria used in the study.

Two starkly dissimilar stages emerge. Between 1974 and 2001, the middle sections of society shrank rapidly and the low class expanded substantially. Between 2003 and 2010, these trends were sharply reversed, but to differing degrees in the different social strata. The middle 
and low classes, in that order, saw a strong recovery in incomes over those seven years, and this resulted in a sustained distributional improvement. Practically $8 \%$ of the population were absorbed in the ranks of the middle class as it expanded.

The recovery of the middle sections in Argentine society was unprecedented since at least the mid-1970s. It is worth emphasizing that it was the result both of upward social mobility (the shrinking of the low class) and of the contraction of the high class. These developments imply that income redistribution mechanisms were at work, increasing the resources of those in the low and middle segments of the social structure but without producing a shift on a similar scale at the top.

These mechanisms do not seem to have operated in isolation from the workings of the labour market. The decline in unemployment and informal working, especially in the unregistered wage employment category, stands out as the main factor behind the fluctuating movements in the social classes in the long period under analysis. Thus, when the characteristics of occupational status were examined (from a stratification perspective that drew particularly on the tradition of sociology), it was possible to ascertain that there had been an increase in the number of jobs providing greater stability to those holding them. This partially reversed the strong increase in occupational instability that had characterized the last quarter of the twentieth century. It should also be considered that this improvement in job quality went together with more vigorous collective bargaining between workers and employers and periodic increases in the minimum wage, among other factors. These mechanisms tend to compress the pay distribution, as their greatest effects are at the lower end of the income scale. The application of lump-sum pay increases for all workers will have operated in the same direction, as will various social protection measures implemented in the period, with job creation schemes, expanded coverage of pension benefits and the extension of family allowances to the children of informal workers being among the most important.

Besides the overall improvement in the dynamics of the social structure, this study also revealed the persistence of labour market segmentation. In other words, those who succeeded in obtaining a registered job enjoyed a pay advantage over employees in jobs that were not registered with the social security system. Likewise, access to a formal job remained elusive for a quite considerable proportion of individuals in the lowest social stratum. This being the case, it is not surprising that the type of employment obtained should have resulted in social differentiation persisting at increasingly high levels over the long period from 1974 to 2010. In other words, it was possible to ascertain that the wage gap between registered and unregistered workers (and the widening of this gap), together with the high proportion of employment accounted for by the latter, influenced households' membership of a particular social class.

Taken together, all this evidence confirms the urgent need for efforts to reduce the level of undeclared employment in the Argentine economy. It seems unlikely that higher levels of social integration can be achieved unless obstacles to registered employment are removed. It should be recalled that the wage penalty for unregistered wage workers doubled between 1974 and 2010, and has not fallen in the new century so far. Efforts should at least begin in certain sectors where the level of nonregistration is very high, prime examples being retail, construction, the textile and apparel industry and domestic service. In the meantime, it is necessary to enhance and extend the implementation of different social protection measures aimed at reducing the earnings gap between those who obtain a formal job and those who remain trapped in informality.

Lastly, it is worth emphasizing the potential for new research that incorporates methodological contributions from economics and sociology in the examination of changes in the social structure. The present study is an effort in this direction. By using different indicators and criteria drawn from the two disciplines to demarcate social groups, it was possible to establish certain links between distributional shifts, certain prominent features of the labour market and membership of a social class. Continued work along this line of analysis would probably yield detailed knowledge of the vicissitudes of social structures in the twenty-first century. 
Atkinson, Anthony (2008), “Concentration among the rich", Personal Wealth from a Global Perspective, James B. Davies (ed.), Oxford, Oxford University Press.

Atkinson, Anthony and Andrea Brandolini (2011), "On the identification of the "middle class", Working Paper, No. 217, Palma de Mallorca, Society for the Study of Economic Inequality (ECINEQ).

Banerjee, Abhijit V. and Esther Duflo (2008), "What is middle class about the middle classes around the world?", Journal of Economic Perspectives, vol. 22, No. 2, Nashville, Tennessee, American Economic Association.

Birdsall, Nancy (2010), "The (indispensable) middle class in developing countries; or the rich and the rest, not the poor and the rest", Working Paper, No. 207, Washington, D.C., Center for Global Development.

Birdsall, Nancy, Carol Graham and Stefano Pettinato (2000), "Stuck in the tunnel: is globalization muddling the middle class", Working Paper, No. 14, Washington, D.C., Brookings Institution.

Blackburn, M. and D. Bloom (1985), "What is happening to the middle class?", American Demographics, vol. 7, No. 1, January.

Bradbury, K. (1986), "The shrinking middle class", New England Economic Review, September-October.

Burkhauser, Richard V. and others (1999), "Testing the significance of income distribution changes over the 1980s business cycle: a cross-national comparison", Journal of Applied Econometrics, vol. 14, No. 3, John Wiley \& Sons.

Castel, Robert (1997), Las metamorfosis de la cuestión social. Una crónica del salariado, Buenos Aires, Paidós.

Castellani, F. and G. Parent (2011), "Being 'middle-class' in Latin America", Working Paper, No. 305, OECD Development Centre [online] $10.1787 / 5 \mathrm{~kg} 3 \mathrm{jcd} x 4 \mathrm{j} 1 \mathrm{x}$-en

Duclos, Jean-Yves, Joan Esteban and Debraj Ray (2004), "Polarization: concepts, measurement, estimation", Econometrica, vol. 72, No. 6, Econometric Society.

Easterly, William (2001), "The middle class consensus and economic development", Journal of Economic Growth, vol. 6, No. 4, Springer.

Easterly, William, Jozef Ritzen and Michael Woolcock (2006), "Social cohesion, institutions, and growth", Economics and Politics, vol. 18, No. 2, Wiley Blackwell.

Eisenhauer, Joseph G. (2008), "An economic definition of the middle class", Forum for Social Economics, vol. 37, No. 2, Springer.

Erikson, Robert and John H. Goldthorpe (1992), The Constant Flux. A Study of Class Mobility in Industrial Societies, Oxford, Clarendon Press.

Esteban, Joan-María and Debraj Ray (1994), "On the measurement of polarization", Econometrica, vol. 62, No. 4, Econometric Society.

Filgueira, Carlos (2007), "Actualidad de las viejas temáticas: Clase, estratificación y movilidad social en América Latina”, Estratificación y movilidad social en América Latina. Transformaciones estructurales de un cuarto de siglo, Rolando Franco, Arturo León and Raúl Atria (coords.), Santiago, Chile, LOM Ediciones.

Foster, James E. and Michael C. Wolfson (2010), "Polarization and the decline of the middle class: Canada and the U.S.", Journal of Economic Inequality, vol. 8, No. 2, Springer.

Franco, Rolando, Martín Hopenhayn and Arturo León (2011), "The growing and changing middle class in Latin America: an update", CEPAL Review, No. 103 (LC/G.2487-P), Santiago, Chile, April.
Gershuny, Jonathan and Man Yee Kan (2006), Human Capital and Social Position in Britain: Creating a Measure of Wage Earning Potential from BHPS Data, BHPS 1991-2004, Essex, Institute for Social \& Economic Research, University of Essex.

Goldthorpe, John H. and Abigail McKnight (2006), "The economic basis of social class", Mobility and Inequality: Frontiers of Research in Sociology and Economics, Stephen L. Morgan, David B. Grusky and Gary S. Fields (eds.), Stanford, Stanford University Press.

Horrigan, M.W. and S.E. Haugen (1988), "The declining middle-class thesis: a sensitivity analysis", Monthly Labor Review, vol. 111, No. 5, Washington, D.C., Bureau of Labor Statistics.

Hussmanns, R. (2004), "Measuring the informal economy: from employment in the informal sector to informal employment", Working Paper, No. 53, Geneva, International Labour Organization.

ILO (International Labour Organization) (1972), Employment, Incomes and Equality: A Strategy for Increasing Productive Employment in Kenya, Geneva.

Jenkins, Stephen P. (1995), "Did the middle class shrink during the 1980 s? UK evidence from kernel density estimates", Economics Letters, vol. 49, No. 4, Amsterdam, Elsevier.

Kharas, H. (2010), "The emerging middle class in developing countries", Working Paper, No. 285, oECD Development Centre [online] 10.1787/5kmmp8lncrns-en.

Levy, F. (1988), Dollars and Dreams: The Changing American Income Distribution, New York, Norton.

Mincer, J. (1974), Schooling, Experience and Earnings, New York, Columbia University Press.

Prandy, K. (1990), "The revised Cambridge scale of occupations", Sociology, vol. 24, No. 4, Sage.

Pressman, Steven (2007), "The decline of the middle class: an international perspective", Journal of Economic Issues, vol 41, No. 1, M.E. Sharpe Inc.

Ravallion, Martin (2010), "The developing world's bulging (but vulnerable) middle class", World Development, vol. 38, No. 4, Amsterdam, Elsevier.

Rosanvallon, Pierre (1995), La nouvelle question sociale. Repenser l'État-providence, Le Seuil.

Rosenthal, N. (1985), "The shrinking middle class: myth or reality?", Monthly Labor Review, vol. 108, No. 3, Washington, D.C., Bureau of Labor Statistics.

Solimano, Andrés (2009), "Stylized facts on the middle class and the development process", Stuck in the Middle: Is Fiscal Policy Failing the Middle Class?, A. Estache and D. Leipziger (eds.), Washington, D.C., Brookings Institution Press.

Thurow, Lester (1987), "A surge in inequality", Scientific American, vol. 256 , No. 5 .

(1984), "The disappearance of the middle class", New York Times, 5 February.

Wright, Erik Olin (2009), "Understanding class. Towards an integrated analytical approach", New Left Review, No. 60, London. (1997), Class Counts: Comparative Studies in Class Analysis, Cambridge, Cambridge University Press. 